\title{
The Venus of our anxiety. The first art was visceral.
}

\author{
Cabeça, Paulo Tiago.
}

Keywords: creativity; prehistoric art; conscious; subconscious, ceramics, clay, art philosophy.

\begin{abstract}
This study represents the continuation of published research work ${ }^{1}$. The aim is to demonstrate the phenomenon of artistic creativity in clay as a process of the conscious and the subconscious. To this end, we analyze aspects of this form of art from its manifestations during the Paleolithic Age to the present day. Why did Paleolithic Man produce so many figures of Venus in stone, bone and clay? What is the secret of the Paleolithic Venus?
\end{abstract}

\section{Clay as a material for self-expression}

Behavioral psychologist João Luis Bucho², who uses clay with his patients as a medium for conducting therapy, refers to this characteristic of the material and our relationship with $\mathrm{it}^{3}$. He states that through the use of clay a Zone of Near Development (Vygotskian, 1987) is established, encompassing both subject and creator, which stimulates the perception, attention, cognition and sensation, as well as encouraging the symbolic and the imaginary. Clay thus acts as a "transitional object" between the world of fantasy and reality. "Expressions of Art in clay ... represent the manifestation of thoughts, feelings, conflicts, anxieties, questions (...) and establish a dialogue between the conscious and the unconscious." ${ }^{4}$. Bucho holds that mastering clay is an achievement, especially for those who have never done this before. The transposition of interior images to the molded object, which often occurs unconsciously, allows us, even in a rudimentary manner, to dominate our emotions, sensations, trauma and anxieties, and thus helps us to gain a measure of contol over the subject. Thus, the troubles of the human mind are appeased, producing a profoundly therapeutic effect.

We often come across such an appeasing effect in artists and inquisitive people who mold clay. Very often, for the artist, on embarking on the production of a work of art,

\footnotetext{
${ }^{1}$ Cabeça, Paulo, et al., 2020, Antologia de Ensaios LABORATÓRIO COLABORATIVO: Dinâmicas Urbanas, Património, Artes, VI Seminário de Investigação, Ensino e Difusão, DINÂMIA'CET-ISCTE. pp. 295.

${ }^{2}$ Psychologist, expressive therapist and master in creativity and innovation. Consulted on December 29, 2018. Available at https://www.joaoluisbucho.com/

${ }^{3}$ Bucho, João Luis, Expressive therapies and clay: vehicle of self-knowledge, creativity and expression, Institutional Repository of The Fernando Pessoa University, Master's dissertations, 2011. Consulted on December 29, 2018. Available at https://bdigital.ufp.pt/handle/10284/2260

${ }^{4}$ Bucho, João Luis, Op. cit.
} 
there is an imperative urge or craving - a necessity - akin to eating or drinking, for creativity. When the piece has been completed, there is a sense of appeasement and tranquility - a feeling of self-realization that settles the artist.

\section{What is creativity?}

Kampylis and Valtanen (2010) state that there are more than 40 definitions of creativity, while according to the authors some concepts of creativity intersect. Those found in the literature in the field are usually referred to as the four Ps of creativity (Richards, 1999): person, process, pressure and product. Thus, some authors can be regarded as agreeing, albeit their definitions of the concept overlapping rather than coinciding exactly. The following notions commonly appear in definitions of creativity:

1. Creativity is a key individual skill.

2. Creativity assumes the existence of an intentional activity or process.

3. The creative process occurs in a specific context or environment.

4. The creative process originates a product, tangible or intangible. This creative product must be new, original, unconventional, and appropriate, useful - at least from the perspective of the creator.

According to the various experts in the field, these characteristics of human creativity are repeated over time. The potential for creativity exists in us all and is activated by intention operating within the context of a specific environment, which necessarily gives rise to an outcome.

Stating that anyone can become a creative person, Sternberg and Lubart (1991, 1993, 1995, 1996) expanded this view, setting out six distinct but related factors which are considered as indispensable resources for creative expression: intelligence, intellectual styles, knowledge, personality, motivation, and environmental context. Their Investment Theory has some features in common with ${ }^{5}$ other theories (see Amabile, 1983, and Csikszentmihalyi, 1988a, 1988b, 1988c).

According to Sternberg, creativity is largely the result of a decision to create being made. Being dependent on such a decision, it is therefore a conscious, rational process. This suggests to Sternberg that creativity can be developed. To be creative, one has to decide to have new ideas.

A person may possess analytical, synthetic or practical tendencies, but may not necessarily use them in activating their creative potential. Consequently, they will not become a creative person.

\section{Limitations of the concept}

Artistic expression is often more a rational or conscious choice - as defined by the theories of Pollock, Van Gog, Munch and many others - than something instinctive or subconscious. However, is it indeed a conscious, analytical or rational choice or rather a form of emotional, anxiety-produced, visceral self-expression? Their definitions

\footnotetext{
${ }^{5}$ Sternberg, Robert J., 2006, The Nature of Creativity. Creativity Research Journal, Tufts University, Massachusetts, Vol. 18, No. 1, pp. 87-89. Consulted on January 15, 2019. Available at https://www.cc.gatech.edu/classes/AY2013/cs7601_spring/papers/Sternberg_Nature-of-creativity.pdf
} 
describe the conscious element of the phenomenon of creativity in art. However, the indications are that there is another less rational aspect involved: that of creativity, deriving from the subconscious. Animals demonstrate a degree of creativity. Kaufman A.B., Butt A.B., Colbert-White E.N. and Kaufman J.C. (2011), on the basis of the neurobiology of animal creativity, define creativity in humans according to Plucker \& Beghetto, (2004). In the former text, with reference to animals, the authors apply "the theory of creativity in humans as a whole, feature by feature, to animal creativity (...) while omitting those that do not apply." Thus, parrots know how to count, understand the concepts of same and different, and acquire language without direct training; in National Geographic magazine (National Geographic, Ark Photo: Chimpanzee, 2015) chimpanzees are portrayed as using basic tools such as wands to catch ants; during the Lindblad Expeditions (National Geographic, 2018), orcas were demonstrated to have developed seal hunting and predation techniques using fluid dynamics, and tonic immobility to hunt sharks (National Geographic, How orcas hunt great whites fascinates biologists, 2020). Such observations support the theory that creativity may be a transversal biological phenomenon which is common to many species.

\section{Survival and continuity}

Art is, in fact, a form of self-expression. And self-expression is a necessity. Those who express themselves have a need to do so. Such a necessity is as basic as breathing, eating, drinking, and seeking shelter from the elements.

Animals also express themselves, communicate by using sounds, movements and rituals. Man has learned to do this in a more complex way, through language, writing, and art, and creativity in art mirrors this complexity. If we consider human existence reduced to its essentials, stripping away the expression of subtlety, we find at the root of everything the most basic needs, for survival and continuity. And this is true not only of humans.

In prehistoric art, there are two major themes: animal and woman, representing survival - portrayed through the animals that were hunted for food or that preyed on humans and the continuity of the species - portrayed as woman who gives birth to new life. Paleolithic Man did not rationalize images; he merely expressed them. In producing the figure of woman - the so-called Paleolithic Venus - the attributes of the female as a life-generating being were emphasized: voluminous breasts, prominent hips and explicit sexual organs; by contrast, her head, feet and hands were never emphasized to such a degree. Interaction between humans over long distances and cultural sharing between groups may account for universal traits in the shape and design of such images, in particular, the profuse representation of the female, if we consider that Man migrated over thousands of kilometers up to the time when humans began to exhibit evidence of behavioral modernity, encountering adverse geographies, monstrous predators, disease, and accidental circumstances. Another reason for the universal nature of expression may be because while creativity is regarded as a conscious phenomenon it may also be a subconscious process, and can be regarded as a biological response which is common to all human beings.

Thus, primeval expressions of artistic creativity were apparently visceral in nature, originating in the subconscious. Everything that calls into question our existence causes us great anxiety and this must be expressed. Appeasement of this anxiety, in form of its materialization, involving its physical manipulation, is revealing of such urgency and absolute need. Self-expression brings reassurance, while there is no choice involved in the matter: we are dealing with an imperative force. As João Bucho points out, there exists 
the opportunity for bringing up from the subconscious to the real world images and events which we cannot otherwise control, and in this way our anxiety can be manipulated, transformed and dominated.

\section{Conclusion}

Survival and continuity are the primeval visceral impulsions of any biological or social being. Man the human hunter-gatherer was the only animal which was capable of expressing itself through Art. He represented animals and women: the former provided for the survival of the species while the latter - the Paleolithic Venus - provided for its continuity. Prehistoric art, the first expression of Man's creativity, is thus demonstrably visceral in nature: the expression of two primeval ancestral anxieties, firstly for hunting as an action that appeases the troubles of the mind, which is essential, and secondly, for the representation of Venus, which constituted the expression of concern for the survival of our genes. 